\title{
An Assessment of the Priorities and Efficiency of Pakistan's Public Sector Educational Expenditure
}

\author{
SHAHRUKH RAFI KHAN, NAUSHIN MAHMOOD and REHANA SIDDIQUi*
}

\section{INTRODUCTION}

Expenditure on education is very often justified on the grounds that it is the means of providing equality of opportunity. Actually, at least two related factors prevent each child from getting an equal chance to flourish academically. Firstly, in a dual system of education, elite private schools coexist with the often substandard government schools (urban and rural) and private schools. Entrance into the elite private schools is based on influence or wealth. The recipients of this schooling are prepared for better careers, with acquired ability and contacts paving the way.

Secondly, in the existing social structure, the poor are not able to take advantage even of existing facilities. While wealthy and educated parents are likely to take an interest in their children's education, to provide a stimulating home environment, and to instil into them the value of education, the poor often withdraw their offspring from school not only to avoid schooling expenses but also to make the offspring supplement meagre family incomes through (menial, low-paid) jobs. Even if some offsprings of poor parents somehow manage to complete school education, their motivation for further education is often blunted by the discrimination they observe in the labour market.

We mention this emphatically because the secondary published data we relied on for our analysis required us to take the present education system as given. Naturally, the conclusions we drew from such an analysis did not concern the abovementioned principal issues, which are widely known but repeatedly overlooked.

This paper mainly analyses the priorities and performance of public-sector education, using data on provincial educational expenditure over the past decade to determine the 'efficiency' of both administration and resource use in the education sector. However, the problem in such an assessment is that there is no standard by 
which to measure efficiency. Because of this constraint, we decided to make a comparative study of the performances of the public-sector education in the four provinces of Pakistan. Since education is in large part a provincial responsibility, such an analysis is useful for providing feedback, to the provincial administrations, of relative strengths and weaknesses of their educational system. Also, dramatic differences in priorities and performance among provinces provide useful insights, and, more importantly, raise many questions for planners. Such an analysis is also necessary for overall resource allocation. As a background, we also give an account of the educational development over the past decade. In doing so, we often divide the data to correspond with plan periods to see if and how the data reflect the changing priorities.

Our analysis focuses on primary and secondary schooling, partly because of the important finding that primary education, followed by secondary education, shows the highest social and private rates of return. The oft-stated goal of planners to attain universal literacy could also be assessed from the priorities given to these two levels of education.

\section{EDUCATIONAL DEVELOPMENT IN SOUTH ASIA AND PAKISTAN}

A general appraisal of educational performance in South Asia reveals that despite an otherwise reasonable level of socio-economic development achieved over the last decade, Pakistan's relative position in education has deteriorated compared to its five neighbouring countries. Statistics on enrolments and public expenditure indicate that it moved from the third position in 1970 to the fifth in 1980. Among these countries, Pakistan had the lowest percentage (4.6\%) of total government expenditure on education in 1980 - this despite the fact that the countries used for comparison themselves rank among the least developed countries.

\section{THE NATIONAL AND PROVINCIAL EMPHASIS ON EDUCATION}

Internally, in sectoral resource allocations, Pakistan's educational sector ranked seventh in all the Five-Year Plan periods. The NWFP, Sind and the Punjab governments allocated about 10 percent of their budgets to education in the Fifth Plan period. Although, except in Sind, provincial allocations to the educational sectors, compared with those in the Fifth Plan period, have declined, the amounts allocated do compare favourably with the average overall budgetary allocations for education in South Asian countries. Baluchistan's emphasis on education is the lowest; its allocation is one-half of that of the other provinces. However, the problem in Baluchistan, judging from its low student/institution ratios, is likely to be on the demand side rather than on the supply side, for adequate educational facilities already exist.

\section{PROVINCIAL DEVELOPMENT EXPENDITURE PATTERNS}

In the provinces, the pattern of educational development expenditure over the last decade reveals a very noticeable structural change. In the $1970-78$ period, the provincial emphasis in terms of development expenditure allocated to the different levels of education was diverse. Baluchistan did not have a marked emphasis on any one level, while the NWFP's was on primary education, Sind's was on technical and professional education, and the Punjab's was on secondary education.

During the Fifth Plan period (1978-83), the expenditure on primary education and, to a lesser extent, on secondary education showed a dramatic rise in all the provinces. In fact, except in Baluchistan (which received the largest funds for secondary education), primary education claimed the highest priority, with secondary education following it (Table 1). Estimated from the figures in Table 1, these two levels of education, on an average, absorbed 31 percent of the total provincial development expenditure as compared with 14 percent and 19 percent, respectively, in the Annual Plan period. This shift corresponded with the priorities outlined in the Fifth Plan [10, Chap. 20, pp. 7-8].

The other major objective of the Fifth Plan was to curtail expenditure on university education. The Sixth Plan emphasizes these objectives also, specifically mentioning the need to remedy the "inverted pyramid syndrome" [11, p. 338]. However, our estimates indicate that university expenditure has gone up from an average share of 17.5 percent to that of about 19 percent in the total development expenditure on education. For other levels of education, there has been a fall in expenditure in all cases. This fall is significant in the cases of technical education in Sind and college education in Baluchistan.

The broad orientation of the educational philosophy of the two plans appears to have a sound economic footing; for as Table 2 indicates, in developing countries the returns to society from investment in education are highest in primary education, second highest in secondary education, and lowest in higher education.

This evidence is supported by the rates of returns computed for Pakistan by Hamdani [3, p. 156]. A 1974 study conducted for the Bureau of Educational Planning showed similar results [8, pp. 28-29]. In both cases, the results were robust in that they were insensitive to large changes in the data underlying the calculations.

\section{FINANCING OF EDUCATION}

An emphasis on primary and secondary education also helps in attaining the stated goal of universal literacy by casting wide the educational net. It will be socially productive as it would help to reach a large talent pool, and it will also be socially equitable in that it would draw the poor into the educational system. However, there are at least two reasons to believe that the equity objective is perhaps 
Average Percentage Distribution of Development Expenditure on Education

\begin{tabular}{|c|c|c|c|c|c|c|c|c|}
\hline \multirow{2}{*}{$\begin{array}{c}\text { Head of } \\
\text { Expenditure }\end{array}$} & \multicolumn{2}{|c|}{ Punjab } & \multicolumn{2}{|c|}{ Sind } & \multicolumn{2}{|c|}{ NWFP } & \multicolumn{2}{|c|}{ Baluchistan } \\
\hline & $\begin{array}{c}1972-73- \\
1977-78\end{array}$ & $\begin{array}{c}1977-78- \\
1982-83\end{array}$ & $\begin{array}{c}1972-73- \\
1977-78\end{array}$ & $\begin{array}{c}1977-78- \\
1982-83\end{array}$ & $\begin{array}{c}1972-73- \\
1977-78\end{array}$ & $\begin{array}{c}1977-78- \\
1982-83\end{array}$ & $\begin{array}{c}1972-73- \\
1977-78\end{array}$ & $\begin{array}{c}1977-78- \\
1982-83\end{array}$ \\
\hline \multicolumn{9}{|c|}{ Primary Education } \\
\hline $\begin{array}{l}\mathrm{a} \\
\mathrm{b}\end{array}$ & $\begin{array}{l}13.2 \\
(8.90)\end{array}$ & $\begin{array}{c}29.3 \\
(13.98)\end{array}$ & $\begin{array}{l}10.5 \\
(8.91)\end{array}$ & $\begin{array}{l}30.3 \\
(9.83)\end{array}$ & $\begin{array}{c}22.2 \\
(11.99)\end{array}$ & $\begin{array}{l}46.5 \\
(4.41)\end{array}$ & $\begin{array}{l}10.5 \\
(9.18)\end{array}$ & $\begin{array}{l}19.7 \\
(7.20)\end{array}$ \\
\hline \multicolumn{9}{|c|}{ Secondary Education } \\
\hline $\begin{array}{l}a \\
b\end{array}$ & $\begin{array}{l}21.0 \\
(7.10)\end{array}$ & $\begin{array}{c}24.7 \\
(11.2)\end{array}$ & $\begin{array}{l}11.3 \\
(6.47)\end{array}$ & $\begin{array}{l}21.7 \\
(5.46)\end{array}$ & $\begin{array}{l}17.8 \\
(7.25)\end{array}$ & $\begin{array}{l}23.8 \\
(6.79)\end{array}$ & $\begin{array}{l}25.0 \\
(31.03)\end{array}$ & $\begin{array}{c}29.7 \\
(10.27)\end{array}$ \\
\hline \multicolumn{9}{|c|}{ Teachers' Training } \\
\hline $\begin{array}{l}a \\
b\end{array}$ & $\begin{array}{c}6.8 \\
(5.08)\end{array}$ & $\begin{array}{c}4.8 \\
(5.04)\end{array}$ & $\begin{array}{l}1.7 \\
(8.71)\end{array}$ & $\begin{array}{c}7.3 \\
(10.88)\end{array}$ & $\begin{array}{c}2.0 \\
(0.89)\end{array}$ & $\begin{array}{l}3.7 \\
(1.51)\end{array}$ & $\begin{array}{c}7.8 \\
(2.40)\end{array}$ & $\begin{array}{l}13.5 \\
(8.55)\end{array}$ \\
\hline \multicolumn{9}{|c|}{ Technical Education } \\
\hline $\begin{array}{l}a \\
b\end{array}$ & $\begin{array}{l}14.8 \\
(5.08)\end{array}$ & $\begin{array}{l}11.8 \\
(5.04)\end{array}$ & $\begin{array}{l}32.3 \\
(8.71)\end{array}$ & $\begin{array}{c}14.2 \\
(10.88)\end{array}$ & $\begin{array}{c}8.7 \\
(2.73)\end{array}$ & $\begin{array}{c}6.5 \\
(1.64)\end{array}$ & $\begin{array}{l}3.8 \\
(7.49)\end{array}$ & $\begin{array}{c}3.5 \\
(4.59)\end{array}$ \\
\hline \multicolumn{9}{|c|}{ College Education } \\
\hline $\begin{array}{l}a \\
b\end{array}$ & $\begin{array}{l}9.8 \\
(2.56)\end{array}$ & $\begin{array}{l}8.0 \\
(2.97)\end{array}$ & $\begin{array}{l}12.0 \\
(6.03)\end{array}$ & $\begin{array}{l}14.8 \\
(3.86)\end{array}$ & $\begin{array}{l}17.5 \\
(4.88)\end{array}$ & $\begin{array}{l}10.7 \\
(3.28)\end{array}$ & $\begin{array}{c}23.0 \\
(13.63)\end{array}$ & $\begin{array}{l}11.0 \\
(7.29)\end{array}$ \\
\hline & & & & & & & & Continued \\
\hline \multicolumn{9}{|c|}{ Table $1-($ Continued $)$} \\
\hline \multicolumn{9}{|c|}{ University Education } \\
\hline $\begin{array}{l}a \\
b\end{array}$ & $\begin{array}{l}11.0 \\
(3.29)\end{array}$ & - & $\begin{array}{l}15.3 \\
(5.64)\end{array}$ & - & $\begin{array}{l}16.5 \\
(6.09)\end{array}$ & - & $\begin{array}{c}27.2 \\
(26.88)\end{array}$ & $\begin{array}{l}- \\
-\end{array}$ \\
\hline \multicolumn{9}{|l|}{ Scholarships } \\
\hline a & $\begin{array}{l}15.3 \\
(4.76)\end{array}$ & $\begin{array}{c}8.8 \\
(3.97)\end{array}$ & $\begin{array}{c}9.7 \\
(6.25)\end{array}$ & $\begin{array}{c}4.3 \\
(0.82)\end{array}$ & $\begin{array}{c}6.7 \\
(4.55)\end{array}$ & $\begin{array}{c}4.2 \\
(0.98)\end{array}$ & $\begin{array}{l}0.5 \\
(1.22)\end{array}$ & $\begin{array}{l}0 \\
0\end{array}$ \\
\hline
\end{tabular}

Source: Planning Commission [9]

Note: Columns do not add to one hundred because the miscellaneous category has been left out.

- = Data not available.

$\mathrm{a}=$ Average expenditure for the period (in percentage)

$\mathrm{b}=$ Standard deviation. 
Table 2

Table 3

The Returns to Education by Level and Country Type

\begin{tabular}{|c|c|c|c|c|c|c|c|}
\hline \multirow{2}{*}{$\begin{array}{l}\text { Country } \\
\text { Type }\end{array}$} & \multirow{2}{*}{$\begin{array}{c}\text { No. of } \\
\text { Countries }\end{array}$} & \multicolumn{3}{|c|}{ Private Returns } & \multicolumn{3}{|c|}{ Social Returns } \\
\hline & & $\begin{array}{l}\text { Primary } \\
\text { education }\end{array}$ & $\begin{array}{l}\text { Secondary } \\
\text { education }\end{array}$ & $\begin{array}{l}\text { Higher } \\
\text { education }\end{array}$ & $\begin{array}{c}\text { Primary } \\
\text { education }\end{array}$ & $\begin{array}{l}\text { Secondary } \\
\text { education }\end{array}$ & $\begin{array}{l}\text { Higher } \\
\text { education }\end{array}$ \\
\hline \multicolumn{8}{|c|}{ Percentages } \\
\hline Poor & (22) & 29 & 19 & 24 & 27 & 16 & 13 \\
\hline Intermediate & (8) & 20 & 17 & 17 & 16 & 14 & 10 \\
\hline Rich & (14) & - & 14 & 12 & - & 10 & 9 \\
\hline
\end{tabular}

Source: [12]

being side-stepped. Firstly, the percentage of development expenditure devoted to scholarships has declined considerably over the last decade from an average of eight percent for all the provinces to about four percent (Table 1). Secondly, the level of subsidy for public education is currently well over 90 percent and, as is evident from the ratios of receipts to expenditure, it has been rising over the last decade.

Given the independent estimates of unit cost (i.e. cost per student) and the 1980-81 receipt structure by level, we estimated the level of subsidy by province. The subsidy structure that emerges from this is shown in Table 3.

These estimates remain intended subsidies until it can be ascertained that the receipt structure given in Table 3 was actually applied to students enrolled at different levels. On being able to find data on provincial government receipts actually collected and dividing these by total allocations, we estimated the implicit subsidies for some levels of education (Table 4). The implicit subsidies appear to be very close to those presented in Table 3.

Not only is the level of subsidy high, but even the actually collected receipts as percentage of collectable receipts were quite low in 1981. Complete data were not available for Baluchistan's receipt structure, but if we assume it to be the same as that for the NWFP, then our calculations show that in that province, 94 percent of the collectable receipts were actually collected.

With specified welfare criteria, it may be possible to show that such a nondiscriminatory receipt structure (across income groups) is inequitable - especially at the higher levels - given the tax-incidence of overall government expenditure. We suggest that such a high level of public subsidy at all levels for all students may be an unjustifiable burden on the budget of a developing country. To sustain the system as it is may be possible, but to make qualitative improvements would be extremely difficult under these circumstances. It may therefore be high time to reverse the process of increased subsidization and to recover more of the expenditure through a selectively applied user charge (i.e. some form of means test).

Costs, Receipts and Intended Subsidies per Student by Level of Education and Province

(Rupees)

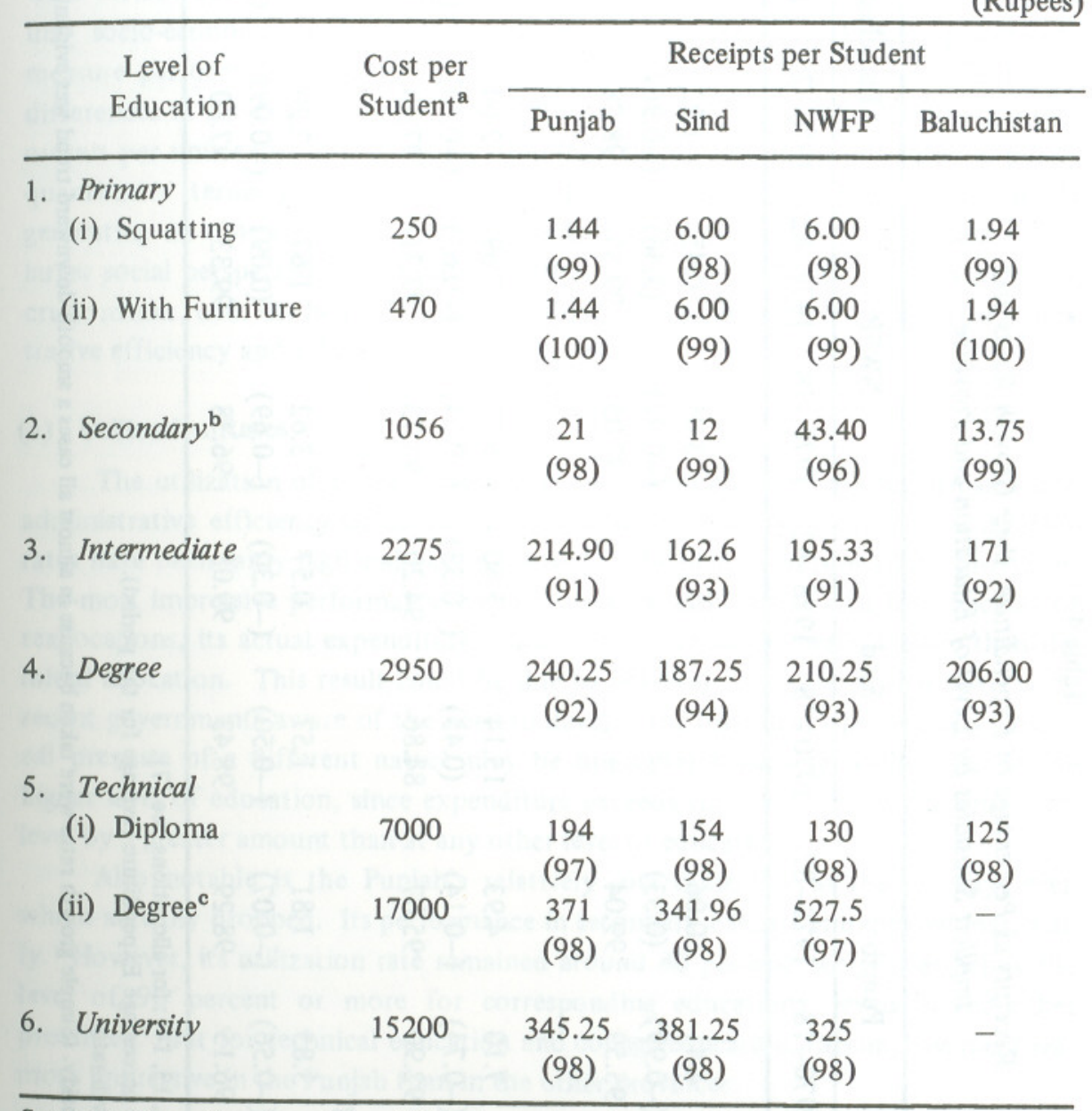

Sources: For unit cost, see [6, p. 181]. For total receipts, see Ghafoor [2, Annex. 5].

Notes: ${ }^{2}$ In calculating intended subsidy, we have assumed that costs per student are identical across provinces. Separate estimates were not available. ${ }^{b}$ Average of middle and high schools.

${ }^{c}$ Average of B.Sc. Engineering and M.B.B.S.

(1) Figures in parentheses represent subsidies in percentages.

(2) We have included only receipts like admission and tuition fees that would ordinarily apply to all students. Thus, fees applying to hostels, transport, field work, degree duplication and re-admission are excluded. This procedure overstated the intended subsidy by a small amount.

(3) At the higher education level, the receipts across different fields of specialization are averaged. This implicitly assumes equal enrolment across the fields. This introduces only small inaccuracies in our calculations since at any given level the receipt rates are quite similar. 


\section{EFFICIENCY OF THE PROVINCIAL EDUCATION SYSTEMS}

In attempting to assess the efficiency of the educational system, one is faced with certain difficulties and problems. The lack of a standard, geared to a partic ular socio-economic and cultural context and capable of making it possible to measure performance, is a major problem. Although the costs are identifiable, the differences in the costs of delivery in different settings make it difficult to compare output per unit expenditure. Apart from that, the measurement of quality in purely quantitative terms is problematic. Finally, there is the problem of efficiently generating an output, which may be already in excess supply in the context of the larger social perspective. Undaunted by these complex problems, we devised some crude means, with the help of the available data, of tackling the issue of both administrative efficiency and efficiency of reosurce use.

\section{(a) Utilization Rates}

The utilization of allocated resources can be reflective of the performance and administrative efficiency of an educational system. Our finding is that utilization rates have been fairly high and have improved in the plan periods in all the provinces. The most impressive performance has been that of Baluchistan. In fact, because of reallocations, its actual expenditure, on average, is about 30 percent more than the initial allocation. This result could be due to political compulsions that have made recent governments aware of the need to develop the least developed regions. Political pressure of a different nature may be operative in causing reallocation at the higher level of education, since expenditure exceeds the allocation at the university level by a greater amount than at any other level of education.

Also notable is the Punjab's relatively low utilization at the primary level, which actually dropped. Its performance in secondary education improved marginally. However, its utilization rate remained around 80 percent, which was below the level of 90 percent or more for corresponding educational levels in the other provinces. But for technical education and college education, this improvement was more impressive in the Punjab than in the other provinces.

\section{(b) Institution-Expenditure Relationships}

Having observed high utilization rates, we now try to determine how far these high rates have been reflected in the increased numbers of institutions. On the assumption that the quality of service availability is everywhere similar, it is possible to compare the expenditure-institution ratios of the four provinces. Using a simple linear regression model, we attempted to estimate whether changes in the number of primary-and secondary-level institutions are significantly explained by variations in expenditure at these levels. 
Regressing a change in institutions on expenditure and lagged expenditure, we found that for a given unit expenditure at the primary school level, the Punjab produced 33 institutions, Sind 31, and the NWFP 26 institutions. The result for Baluchistan was not significant. At the secondary level, the Punjab produced 13, Sind 9, and Baluchistan 10 institutions. The result for the NWFP was not significant. The combined result however showed Baluchistan generating the greatest number of institutions per unit expenditure. These results need to be cautiously accepted because of the likely differences in the nature of both costs and output between different provinces.

Hence, the performance and efficiency of educatonal expenditure are shown by three indicators, viz. ratio of collected receipts to collectable receipts, the development expenditure utilization rates and the institution-expenditure relationship. The ability of an educational system to enrol students, prevent drop-outs and to graduate them is also reflective of its efficiency. However, these issues concern the demand side of education, whereas expenditure is a supply-side phenomenon. In another study which is in progress [4], we have shown that primary schools are unable to retain their students owing to both demand- and supply-side considerations. Thus, for example, both student-teacher ratios and per capita farm-sector real income proved to be highly significant variables in preventing drop-out.

\section{POLICY RECOMMENDATIONS}

Probably our most important recommendation, based on UNESCO recommendations and comparisons with other South Asian countries, is that more funds should be allocated to public-sector education. However, we would also simultaneously recommend that more of this expenditure should be recovered for reinvestment from those students whose financial background would clearly disqualify them for a subsidy. Finally, we suggest that the subsidy should be aimed at primary and secondary education. The indirect costs of education (i.e. the opportunity cost of keeping children in school) are a more important obstacle. These could be dealt with by linking mechanisms so that qualificaton for equity-oriented government-allocation of credit or other agricultural inputs is partly linked to the number of school-going children actually in school. The direct costs are more easily dealt with by selectively waiving receipts that are due and providing subsidized books and uniforms.

\section{REFERENCES}

1. Baluchistan. Finance Department. Estimates of Receipts. Quetta. (For the years $1970-71$ to $1982-83$ )

2. Ghafoor, Abdul. "The Effects of New Trends in Educational Financing on the Plan Objectives: Equity, Quality and Efficiency - A Case Study of Pakistan”. Islamabad: Planning and Development Division. January 1982. (Mimeographed)

3. Hamdani, K. A. "Education and the Income Differential: An Estimation for Rawalpindi City”. Pakistan Development Review. Vol. XVI, No. 2. Summer 1977. pp. 144-164.

4. Khan, S. R., Naushin Mahmood, and Rehana Siddiqui. "School Level Enrollment, Drop-out and Output Patterns in Pakistan: 1970-71-1982-83”. Islamabad: Pakistan Institute of Development Economics. September 1984. (Unpublished, available from the authors on request)

5. N.W.F.P. Finance Department. Estimates of Receipts. Peshawar. 1970-71 to 1982-83.

6. Pakistan. Finance Division. Economic Adviser's Wing. Pakistan Economic Survey: 1982-83. Islamabad. 1983.

7. Pakistan. Ministry of Education. Bureau of Educational Planning. Budget Statistics on Education of the Central and Provincial Governments. Islamabad. (Various issues)

8. Pakistan. Ministry of Education. Bureau of Educational Planning. Pakistan Education 1974: A Sector Assessment. Islamabad. October 1974.

9. Pakistan. Planning Commission. Annual Plans. Islamabad. For the years from $1974-75$ to $1982-83$.

10. Pakistan. Planning Commission. "Draft Fifth Five Year Plan (First Version) 1976-81”. Islamabad. January 1976.

11. Pakistan. Planning Commission. The Sixth Five Year Plan, 1983-88. Islamabad. 1984.

12. Psacharoupoulas, G. "Returns to Education: An Updated International Comparison”. In Timothy King (ed.), Education and Income. Washington, D.C.: World Bank. July 1980. pp. 73-110.

13. Punjab. Finance Department. Estimates of Receipts. Lahore.

14. Sind. Finance Department. Estimates of Receipts. Karachi. 


\section{Comments on}

\section{"An Assessment of the Priorities and Efficiency of Pakistan's Public Sector Educational Expenditure"}

The authors may perhaps be reassured to learn that, as I am a teacher, education is a subject dear to my heart. Unfortunately, I can lay no special claim to any knowledge of the economics of education. I would, therefore, request them not to interpret the few words and remarks I will be making as any reflection on the quality of the data. I intend rather to highlight some of my own difficulties as I have tried to interpret their exercise. My chief trouble, on first reading the paper, began with my inability to find an adequate correspondence between the hopes raised by the title of the paper and the contents of the paper. It appears to me that this first difficulty could be resolved more easily by modifying the title of the paper than by changing its contents. One title that I found appropriate is as follows: A Review of Pakistan's Public Sector Education Expenditure. I am sure that the authors would come up with even a more appropriate title. In any case, I do not think the narrower and perhaps sharper focus suggested by the existing title has been adequately taken care of in the paper.

The paper does primarily provide a review and I have no quarrel with this vital objective. I was not happy to learn that the authors partly share this first difficulty. They state, "In general, the criteria we have used to measure performance are simultaneously internal and comparative". However, the closing sentence of the same paragraph reads: "The problem with this internal criteria is the lack of a standard by which to assess efficiency". It may be that I have misunderstood the authors' intended meaning there because I had a certain difficulty on this score. I stand to be corrected. My previous remark may have made it clear that the authors proposed to employ two criteria to assess the efficiency of resources used in education. These are the internal and the comparative criteria. The authors' internal criterion consists in looking at the utilization ratios of the expenditures allocated to various levels of education. As the authors, too, are fully aware, these utilization ratios cannot measure efficiency of the resources used. This is not to imply that these ratios are, therefore, useless. A comparison of these ratios may perhaps suggest something 
about the relative priorities and/or the difficulties encountered in spending the money allocated to different levels of education. I am not sure, however, about the authors' claim that these ratios measure administrative efficiency. This latter issue and this measurement should more appropriately be left to the students of administrative science.

Let us now turn to the authors' comparative criterion. This has been described as conducting an inter-provincial analysis. The meaning of this criterion becomes clear only towards the end of the paper in a sub-section entitled "InstitutionsExpenditure Relationship". Here, the authors regress changes in the number of institutions on what they somewhat inappropriately describe as development expenditure on education. What they mean by development expenditure is money spent on the physical infrastructure of education, viz. building, furniture and laboratory equipment. The regression coefficients obtained are then taken as a measure of efficiency of the resources used. I am afraid that this is a kind of regression exercise with which I would pick up a quarrel because it is frequently a substitute for more careful economics. Admittedly, the authors refer to the regression coefficients as a crude measure of efficiency because the quality across institutions may not be the same. I think this problem is sufficiently serious to deter us from carrying out such an exercise. In addition, it may be pointed out that apart from quality differentials in the physical infrastructure of institutions, there is also the question of differences in their sizes. In fact, I think that if these quality and size differentials had not existed, 1 would not expect any significant differences in the regression coefficients across provinces. These coefficients would be determined by the cost of the physical infrastructure whose prices across provinces could not be too different. These coefficients would simply measure the unit cost of institutions at various levels. It is my feeling that the authors have been a bit too brave in suggesting that these coefficients measure efficiency, but once again I am not an expert on such matters and I could be wrong.

Having stated my difficulties with the authors' criteria on efficiency, I may be expected to offer an alternative criterion. I am acutely aware that in trying to meet this expectation, I assume the almost certain risk of being wrong myself. But my intuition suggests that one way may be to measure not the private returns to education but the returns to private individuals of total educational expenditure per capita. A more ambitious and therefore unrealizable task would be to measure the social returns to total educational expenditure per capita for various levels of education.

There is a great deal more in this paper that merits detailed discussion but I will restrict myself to one last remark. In an attempt to measure the level of intended subsidy by the level of public sector education, a very useful exercise in itself, the authors have attempted to measure the unit cost of education at different levels, viz. university, secondary and primary. They have measured it by dividing the total expenditure at different levels by enrolments at those levels. The tota expenditure, unfortunately, appears to include both the costs of fixed investment and the recurring expenditure. I would like to point out that it would be more appropriate to use not the total cost of fixed investment but only recurring costs.

Applied Economic Research Centre,

Karachi University,

Shahid Alam 